\title{
Strategia dywersyfikacji w polityce przestrzennej Księstwa Luksemburga
}

\section{Diversification strategy in the spatial policy of the Duchy of Luxembourg}

\section{Streszczenie}

W niniejszym artykule opisana została strategia planistyczna władz Luksemburga, będąca odpowiedzią na zmiany społeczno-gospodarcze, jakie zaszły w wyniku kryzysu krajowego przemysłu. Dywersyfikacja funkcji metropolitarnych ze stolicy na tereny charakteryzujące się słabym rozwojem może przyczynić się do bardziej zrównoważonego rozwoju kraju opartego na finansach i nauce. W artykule zostanie przedstawiony kontekst społeczno-gospodarczy towarzyszący zmianom w polityce przestrzennej.

Słowa kluczowe: planowanie w skali regionalnej, wielkoskalowe projekty urbanistyczne, strategie planistyczne, rewitalizacja terenów kryzysowych, inwestycje publiczno-prywatne

\section{Abstract}

The paper discusses the planning strategy of Luxembourg's authorities as an answer to socioeconomic changes resulting from the crisis in domestic industry. The diversification of metropolitan functions - to areas characterized by poor development may contribute to a more balanced development of the country based on the finance and scientific sectors. The article presents the socio-economic context accompanying changes in spatial policy.

Keywords: planning on a regional scale, large-scale urban projects, planning strategies, revitalization of crisis areas, public-private investments 


\section{WSTĘP. PRZYCZYNY TRANSFORMACJI GOSPODARCZEJ LUKSEMBURGA}

Międzynarodowy kryzys stali lat 70. XX wieku odbił się na gospodarce Księstwa Luksemburskiego. Siła państwa dotychczas była w przeważającej mierze oparta na hutnictwie stali z powodu bogatych złóż minerałów. Kryzys na rynku stali zmusił władze krajowe do zmiany strategii rozwoju gospodarki. Rozwój kraju lat 60/70. XX wieku w większym stopniu miał skupić się wokół klastrów finansów i wiedzy ${ }^{1}$. Idąca za tymi zmianami duża dynamika wzrostu gospodarczego w sektorze usług doprowadziła do przesycenia inwestycjami regionu stolicy kosztem innych obszarów, dotychczas uzależnionych od prosperity w gałęzi przemysłu. Problemem Luksemburga jest „niedobór przestrzenny” powodowany zbyt dużym rozwojem gospodarki w stosunku do wielkościowych możliwości kraju². Odpowiedzią na to zagadnienie była zmiana krajowej polityki przestrzennej poprzez strategię dywersyfikacji i decentralizacji usług i struktur publicznych i administracyjnych. Wyrażać się ona miała poprzez przenoszenie części owych podmiotów do obszarów charakteryzujących się wyraźnie niższym tempem rozwoju gospodarczego lub pozostających w stanie kryzysu. Proces ten ma być impulsem do dekoncentracji prywatnych inwestycji ze stolicy i podniesienia możliwości rozwojowych pozostałych regionów Wielkiego Księstwa. Proces ten organizowany jest w ramach wielkoskalowych projektów urbanistycznych. Daje to szanse na zmniejszenie nierówności rozwojowych Wielkiego Księstwa, dotychczas spolaryzowanego przez naukowo-finansową stolicę i zdecydowanie przemysłowy charakteru reszty kraju, szczególnie południa ${ }^{3}$.

Do lat 60. główną gałąź gospodarczą Luksemburga stanowił przemysł ciężki. Zmiana systemu gospodarczego zbiegła się z jego szybkim rozwojem demograficznym, szczególnie zaś intensywnym od początku lat 90-tych XX wieku. Brak możliwości podtrzymywania dotychczasowej efektywności dawnych zakładów, skłoniły władze Luksemburga do podjęcia konkurencji z innymi krajami na płaszczyźnie usług, w tym szczególnie finansów. Dziś kraj ten jest jednym ze światowych centrów finansowych. Dzięki licznym siedzibom światowych banków, atrakcyjnym zasadom podatkowym, ale także lokalizacji instytucji Unii Europejskiej, Luksemburg utwierdza swoją markę jako kraju nowoczesnego i wybitnie zamożnego ${ }^{4}$. Sukces owej strategii transformacji gospodarczej był w dużej mierze skutkiem zgody na internacjonalizację kraju, wpuszczenie zagranicznego kapitału oraz otwarcia rynku pracy dla cudzoziemców. Aktualnie aż 45\% mieszkańców kraju pochodzi z zagranicy 5 .

\section{KONTEKST SPOŁECZNY REFORM GOSPODARCZYCH I PLANISTYCZNYCH}

Sprowadzenie do Luksemburga unijnej administracji, a także wielkich międzynarodowych korporacji przyczyniło się do dynamicznego wzrostu zapotrzebowania na powierzchnie biurowe oraz wykwalifikowanych pracowników umysłowych. Szczególnie w stolicy kraju jest widoczny duży wzrost inwestycji. Miasto Luksemburg, pomimo iż zamieszkiwane przez mniej 
niż 100 tys. osób, odpowiada za większą część krajowego PKB. Koncentracja usług finansowych oraz administracyjnych w stolicy Księstwa doprowadza do zachwiania na rynku nieruchomości. Wysoki popyt na przestrzenie biurowe w centrum miasta prowadzi do drastycznych wzrostów czynszów lokali mieszkalnych. Czynsze w Wielkim Księstwie są dwukrotnie wyższe aniżeli w sąsiednich Niemczech ${ }^{6}$. Miasto Luksemburg, pomimo przyciągania największych inwestycji, ze względu na trudny układ topograficzny - oferuje bardzo ograniczone możliwości rozwoju zabudowy. Skutkiem tego obserwuje się wzrost liczby luksemburczyków, dla których posiadanie własnego mieszkania w stolicy okazuje się być poza ich możliwościami finansowymi. Beneficjantami tej sytuacji są okoliczne miasta satelickie, które mogą zaoferować niższe czynsze ${ }^{7}$. Jednak niewielki rozmiar kraju skłania wielu do podjęcia decyzji o zamieszkaniu w sąsiednim kraju i dojeżdżaniu do pracy każdego dnia. Dobrze rozwinięta sieć transportu publicznego oraz autostrad zachęca pracowników do większej mobilności. Zjawisko to sprzyja również do podejmowania pracy w Księstwie przez cudzoziemców. Wysokie dochody uzyskiwane w Luksemburgu przy wyraźnie niższych kosztach życia za francuską czy niemiecką granicą pozwalają wielu pracownikom osiągnąć wyższy standard życia kosztem dłuższego dojazdu do pracy. Trudna sytuacja na rynku nieruchomości sprzyja zatem procesowi niekontrolowanego odpływu mieszkańców ze stolicy.

Dynamiczny rozwój gospodarczy przekraczający rozwój demograficzny (każdego dnia 156 tys. osób dojeżdża do pracy spoza granic Luksemburga) skutkuje jednoczesnym brakiem lokalnych rąk do pracy przy ograniczonych możliwościach rozbudowy stolicy (bezrobocie oscyluje wokół 6-7\%) ${ }^{8}$. Niewielki rozmiar kraju skutkuje dużym przypływem pracowników z zagranicy. W 2010 r. 211 tys. mieszkańców kraju nie miało luksemburskiego obywatelstwa. 65\% mieszkańców stolicy stanowią cudzoziemcy ${ }^{9}$. Polityka państwa od 1960 r. sprzyja migracji. Dziś kraj ten jest miejscem pracy dla zdecydowanie większej liczby osób, niż w nim mieszka. Intensywny rozwój przestrzeni biurowych sprawia, że kraj staje się domem dla międzynarodowej rzeszy urzędników. Strategiczne położenie Luksemburga w centrum Europy, w sercu tzw. europejskiego banana, sprzyja wymianie gospodarczej i procesowi drenażu mózgów z krajów ościennych. Bezpośrednio przekłada się to na bliskie związki luksemburskich kantonów z sąsiednimi regionami w oparciu o umowy bilateralne pomagające w wolnej transgranicznej współpracy. Sytuacja ta sprzyja transformacji prywatnego kapitału w kierunku internacjonalizacji.

W szerszym ujęciu koncentracja wielkich międzynarodowych korporacji finansowych oraz instytucji unijnych w stolicy kraju sprzyja spolaryzowanemu rozwojowi Księstwa przy jednoczesnym wzroście długości dojazdów do pracy. Czyni to luksemburski rynek pracy niezwykle hermetycznym. Gospodarka kraju, której rozwój uzależniony jest od dużej liczby wysoko wykwalifikowanych imigrantów, funkcjonuje w realiach kraju nieprzyjaznego do życia. W interesie państwa jest dążenie do zrównoważonego rozwijania całego kraju, w którym poszczególne części są w stanie oferować równe warunki życia i gospodarczy progres. 


\section{ZMIANA STRATEGII PLANISTYCZNEJ KRAJU}

Planowanie przestrzenne w Luksemburgu zostało sprowadzone do dwóch poziomów - ogólnopaństwowego i gminnego. W roku 2003 władze centralne przyjęły program przygotowany przez Ministere de I'Interieur (Ministerstwo Spraw Wewnętrznych) Program Directeur d'amenagement du Territoire ${ }^{10}$. Wyznacza on kierunek strategii planowania przestrzennego gmin i regionów. Przy opracowywaniu strategii brane są pod uwagę takie czynniki jak ochrona krajobrazu, ale również ilość powierzchni przemysłowych, dostępność komunikacyjna, zrównoważony rozwój, czy w końcu mobilność.

Odpowiedzią na problem braku równowagi przestrzennej w realizowaniu nowych inwestycji jest koncepcja dyslokacji części funkcji metropolitarnych ze stolicy do innych ośrodków miejskich. Jest ona również próbą odpowiedzi na problemy wynikające ze wspominanego kontekstu społeczno-ekonomicznego. Decentralizacja ma wzmocnić rozwój usług, zainicjować tworzenie nowych miejsc pracy, przyczynić się do dywersyfikacji ekonomicznej i decentralizacji administracji. Niewątpliwym atutem rezygnacji z rozwoju kraju wokół jednego wiodącego ośrodka miejskiego jest aktywizacja kulturowa ośrodków mniejszych oraz bezpośredni rozwój społeczeństwa. Rozwiązanie to zatem daje szanse podtrzymania rozwoju gospodarki kraju, jednocześnie chroniąc miasto Luksemburg i jego otoczenie przed niekontrolowaną rozbudową. Zakłada się, że funkcje metropolitarne nie muszą być koniecznie organizowane w największych metropoliach ${ }^{11}$. Rozproszenie ich i scedowanie na mniejsze, doskonale skomunikowane ośrodki miejskie pozwalają na uzyskanie bardziej demokratycznego i zrównoważonego rozwoju kraju. Jest to element zmiany w podejściu planistycznym. Aktualnym zadaniem jest umożliwienie racjonalnej rozbudowy kraju wraz z efektywnym systemem komunikacji. Szczególnie istotne jest stworzenie wygodnych i szybkich połączeń transportem zbiorowym z krajami sąsiednimi. Władze centralne starają się wychodzić naprzeciw tym wyzwaniom poprzez realizację wielkich publicznych projektów sytuowanych poza stolicą. Owe zamierzenia urbanistyczne realizowane w częściach kraju o wolniejszym wzroście gospodarczym, albo nawet pozostających z różnych powodów w stanie kryzysowym, mają wyrównywać szanse i przyczyniać się do rozwoju zrównoważonego. Największymi projektami są Kirchberg oraz realizowane dzielnice na terenie huty w Belval oraz Clôche d’Or na południu stolicy. W pierwszym przypadku (projekt realizowany od lat 60. XX wieku) magnesem rozwojowym była lokalizacja licznych instytucji europejskich, w drugim zaś koncepcja przeniesienia z Luksemburgu do Belval Universitat Campus Belval - nowego kampusu Uniwersytetu Luksemburskiego. 


\section{WIELKIE PROJEKTY URBANISTYCZNE - KIRCHBERG, BELVAL I CLÔCHE D’OR}

Pierwszym wielkim założeniem urbanistycznym był Kirchberg - realizowana od lat 60. XX wieku dzielnica. zlokalizowana na dawnych terenach rolniczych po wschodniej stronie Luksemburga. Planowana jako zagłębie instytucji unijnych i bankowych, była największą rozbudową miasta w historii stolicy. Inwestycja była prowadzona przez fundusz Fonds Kirchberg, powołany przez rząd w 1961 r. Jednostka zarządza projektem, odpowiadając za stronę planistyczną, organizację pożyczek na rzecz rozbudowy dzielnicy oraz nadzorując bezpośrednio kwestię realizacji poszczególnych inwestycji na poziomie administracyjnym i budowlanym. Dziś dzielnica oferuje przeszło milion metrów kwadratowych powierzchni biurowej oraz 31 tys. miejsc pracy. Ponadto rejon zamieszkuje jedynie 3 tys. osób. Koncepcję urbanistyczną opracował wybitny francuski architekt Pierre Vago. Dzielnica osnuta wokół głównej arterii komunikacyjnej - Alei Johna F. Kennedy'ego - nie jest związana strukturalnie z centrum miasta, operując odmiennym wzorcem urbanistycznym. Założenie zostało urbanistycznie odseparowane od pozostałej części miasta - co szczególnie podkreśla biegnącą między tą dzielnicą a śródmieściem głęboką doliną rzeki Alzette - oraz zyskało odmienny charakter. Jest to modernistyczna enklawa stolicy. W przeciwieństwie do centrum miasta cechującego się średniowiecznym układem ulic i historyczną skalą budynków, zabudowa Kirchbergu jest luźno ułożona w stosunku do ulicy, zrywa z reżimem pierzei i zasadą mieszania funkcji, ale zachowując przy tym czytelność układu urbanistycznego. Dzielnica zdominowana przez biura, a komunikacja podporządkowana została indywidualnemu ruchowi kołowemu, uzupełniana tylko przez linie autobusowe ${ }^{12}$.

Kirchberg miał umożliwić mieszkańcom i pracownikom wysoki poziom życia i pracy w zielonej dzielnicy oraz być okazją do ukazania Luksemburga jako nowoczesnej metropolii, której historyczny charakter nie będzie krępować kolejnych inwestorów. Mała różnorodność funkcjonalna sprawiała, że główne funkcje metropolitarne stolicy wciąż pozostawały zgromadzone w historycznym śródmieściu. Wobec tego nie ustępowało wysokie zainteresowanie inwestycyjne na realizację nowych inwestycji w dawnym centrum Luksemburga. Ponadto duża rozległość założenia Kirchbergu stworzyła nowe problemy, szczególnie związane z czasem potrzebnym na dojazd pracowników. Od lat 90. XX wieku następuje proces uzupełniania funkcjonalnego dzielnicy oraz nadawania mu bardziej miejskiego charakteru.

Projekt Nowego Belval (Esch-sur-Alzette) jest próbą odciążenia funkcjonalnego i inwestycyjnego stolicy, a także stanowi przykład lokalnego ośrodka, które pomimo swej niewielkiej wielkości może pełnić funkcje metropolitarne. Wynika to ze sposobu funkcjonowania luksemburskiej gospodarki. Niezwykle zinternacjonalizowany system rozwija się w oparciu o liczne sieci połączeń rynku pracy - poprzez funkcjonowanie międzynarodowych korporacji, uczelni, wymianę pracowników, a także często pełnienie funkcji usługowej względem sąsiadujących większych ośrodków lub kompleksów ośrodków miejskich. Ten policentryczny system pozwala korzystać z licznych dóbr oferowanych przez proces globalizacji. Dzielnica 
zrealizowana na terenie dawnej huty stali Belval nie stanowi z miastem Esch-sur-Alzette zwartej struktury urbanistycznej - rozdziela je funkcjonująca część Huty Belval ${ }^{13}$. Podobnie jak inne wielkoskalowe założenia o znaczeniu strategicznym dla kraju, projekt ten koordynowany jest przez spółkę Fonds Belval, która podlega bezpośrednio rządowi kraju. Również na poziomie centralnym definiowane są wytyczne - łącznie z architektonicznymi - dotyczące konkretnej realizacji. Nowe założenie wykorzystuje wyłączone z produkcji tereny hutnicze, bardzo dobrze zintegrowane komunikacyjnie z okolicznymi miejscowościami. Obszar będący w pełni uzbrojony, po przeprowadzeniu rekultywacji gruntów z poprzemysłowych zanieczyszczeń, bardzo łatwo mógł być dostosowany do nowej funkcji. Tereny pohutnicze charakteryzują się rozległością zajmowanych terenów. Cecha ta pozwoliła na zlokalizowanie w jednym miejscu kompleksowego założenia urbanistycznego, łączącego w sobie wszystkie aspekty życia w metropolii. Lokalizacja istotnych w skali kraju instytucji, jak Uniwersytet Luksemburski, była impulsem do realizacji funkcji towarzyszących na tym terenie. Projekt mógł być realizowany jako założenie wzorcowe, oferujące wysoki standard życia. Masterplan wyłoniony w międzynarodowym konkursie w roku 2001 wygrało biuro KCAP Architects \& Planners and Topotek $1^{14}$. Zakłada on podział terenów pohutniczych na cztery części. We fragment, na którym pozostały pohutnicze relikty, jak kominy czy wielkie piece, zostały wkomponowane nowe funkcje i obiekty z sektora kultury, jak np. Rockhal, zaś w odnowionych obiektach pojawiły się przestrzenie wystawiennicze (dzielnica Terrasse des Hauts Fourneaux). Nieopodal zlokalizowano dzielnicę Square Mile, łączącą funkcje biurowe wraz z mieszkalnymi i usługowymi. Obszar zabudowy mieszkaniowej - Quartier Belval - został odseparowany od pozostałej części Nowego Belval rozległym parkiem. Całość założenia umożliwiło stworzenie unikalnej przestrzeni o zharmonizowanym wyrazie architektonicznym, będącą jednocześnie miejscem pracy dla 25 tys. osób oraz dającą mieszkania dla 7 tys. ${ }^{15}$.

Aktualnie realizowana jest kolejna dzielnica Luksemburga, zlokalizowana w jego południowej części. Clôche d’or odróżnia jednak od Kirchbergu masterplan, który uwzględnia skalę i ziarnistość miasta. Założenie zostało sytuowane w obszarze naturalnego rozwoju stolicy. Dzięki przyjętemu w 2005 r. planowi ogólnemu teren ten został uchroniony przed chaotyczną zabudową zdominowaną przez funkcję biurową. Dzielnica ma łączyć wszystkie aspekty zrównoważonego życia miejskiego. Głównym środkiem transportu ma stać się tramwaj oraz komunikacja rowerowa. Celem ustrukturyzowania dzielnicy wprowadzono ograniczenia wysokościowe nowej zabudowy (kwartały mają operować wysokością 22, 36 oraz 60 m). Dzielnicę ma zamieszkiwać około 3 tys. osób, których mieszkania mają cechować się certyfikatem efektywności energetycznej AAA. W Clôche d’or przewidziano również miejsce dla liceum Vauban (2300 studentów) oraz tereny pod funkcję biurową ${ }^{16}$. Program funkcjonalny dzielnicy mają uzupełniać stadion, centrum handlowe oraz park krajobrazowy, który obejmie czwartą część dzielnicy. Charakterystycznym elementem pejzażu Clôche d'or ma została wyłoniona w konkursie architektonicznym wysoka na 70 m wieża ciśnień autorstwa biura Atelier d'Architecture et de Design Jim Clemes $^{17}$. 
Wszystkie te projekty są przykładami wielkich publicznych zamierzeń planistycznych, które pociągnęły za sobą prywatne inwestycje, skutkując rozwojem rynku pracy i nieruchomości. Nakierowane są na usługi z sektora wiedzy i finansów. Pomimo pozytywnego wpływu na lokalną i krajową gospodarkę stanowią samodzielne wyspy prosperity. Charakteryzują je jednak jednolity profil społeczny mieszkańców oraz oderwanie kompozycyjne założenia od rdzennego miasta.

Wielkoskalowe założenia urbanistyczne realizowane są w partnerstwie publiczno-prywatnym, w którym podmiot prywatny gwarantuje kapitał, inwestycje - również w publiczne struktury i infrastrukturę - zaś strona publiczna odpowiada za koordynację zamierzenia od strony administracyjnej. Za realizację podobnych projektów odpowiada każdorazowo powołany fundusz, w którego składzie znajdują się reprezentanci władz centralnych, lokalnych, prywatnych inwestorów czy lokalnej społeczności.

Luksemburg stara się rozwijać graniczne regiony we współpracy z sąsiadami. Utworzenie European Grouping of Territorial Cooperation (EGTC) umożliwiło wprowadzenie autonomicznych struktur prawnych obowiązujących w przygranicznych regionach i umożliwiającą wymianę inwestycyjną, gospodarczą i społeczną między owymi regionami ${ }^{18}$. Współpraca luksembursko-francuska (podpisane konwencje współpracy przygranicznej z 2006 r.) pozwoliła zainicjować we Francji m.in. towarzyszący Belval Biznes-Park. We Francji realizowany jest projekt EcoCité. W jego ramach Francuzi podjęli chęć prowadzenia wspólnej z Luksemburgiem strategii rozwoju przygranicznych miejscowości. Jej wyrazem jest powołana ponadpaństwowa regionalna jednostka administracyjna - Pays Haut Val d’Alzette zrzeszająca owe miejscowości i pomagająca w realizacji wspólnych celów gospodarczych ${ }^{19}$.

\section{KŁOPOTLIWY ROZWÓJ WIELKOSKALOWYCH PROJEKTÓW}

Duża dynamika rozwoju luksemburskiej gospodarki sprawia niestety, że realia inwestycyjne przekraczają możliwości regulacyjne urzędników. Legislatywa, szczególnie zaś na poziomie lokalnym, nie nadąża z wprowadzaniem instrumentów prawnych regulujących proces i warunki realizowania kolejnych inwestycji budowlanych. Władze lokalne nie są w stanie często zapewnić w odpowiednim czasie infrastruktury miejskiej ${ }^{20}$. Zjawisko to dotyczy również możliwości krytycznego i kompleksowego planowania przestrzennego na poziomie lokalnym, co skutkuje brakiem adekwatnej kontroli nad rozwojem nowej zabudowy.

Wielkie międzynarodowe korporacje dążą do realizowania inwestycji w postaci wielkopowierzchniowych kompleksów monokultur biurowych. Powodzenie takiej inwestycji jest nierzadko uzależnione od możliwości realizowania jej na jednym, większym obszarze. Umożliwia to efektywniejsze przeprowadzenie całej inwestycji. Niestety kierunek ten prowadzi do polaryzacji funkcjonalnej, a także kompozycyjno-formalnej. Stąd rozwój takich założeń prowadzi bezpośrednio do rozczłonkowania struktury miejskiej. Najczęściej bowiem nierozproszone 
tereny o potencjale realizacji odpowiednio dużej inwestycji znajdują się z dala od właściwej struktury urbanistycznej, prowadząc do niewłaściwego kierunku rozwoju miasta. Wyraża się to poprzez powstawanie na uboczu samotnych monofunkcjonalnych wysp nowej zabudowy. Niestety dotyczy to zarówno inwestycji w całości prywatnych, jak i wielkoskalowych zamierzeń władz publicznych, gdzie za przykład mogą służyć - wzorcowe w swoim pierwotnym założeniu - realizacja dzielnicy Kirchberg, ale także Clôche d’Or, czy mimo wszystko Belval. Podobne projekty tworzą miejskie enklawy. Przeznaczone najczęściej głównie dla międzynarodowych korporacji biurowych, bankowych, operują odmiennym wzorcem tkanki miejskiej niźli otaczające je miasto. Stanowią obszar doskonale skomunikowany, ale równocześnie położony z dala od struktury miejskiej.

Ogromne założenia, ich wieloaspektowość skutkuje powstawaniem złożonych problemów, którym nie zawsze są w stanie sprostać miejscy urzędnicy. Coraz częściej obserwuje się zobowiązywanie prywatnych podmiotów do prowadzenia procesu inwestycyjnego, co ogranicza możliwość skutecznej kontroli publicznej. Wyraża się to nie tylko w rosnących kosztach inwestycji, czy nieterminowości realizacji, ale także nierzadko pomijaniu aspektu społecznego poprzez realizację w ramach dużych inwestycji interesów lokalnych społeczności ${ }^{21}$. Równocześnie należy pamiętać, iż publiczne wielkoskalowe projekty urbanistyczne są trudne w zarządzaniu i obarczone wielkim ryzykiem. Realizacje koordynowane przez władze centralne pozostają słabo dostosowane do lokalnych problemów, szczególnie zaś z trudem poddają się modyfikacjom.

\section{PODSUMOWANIE}

Wielkie Księstwo Luksemburga jest przykładem kraju, który odniósł sukces, przeprowadzając transformację gospodarczą. Dynamiczny rozwój, jaki następuje od lat 60/70. XX wieku przyniósł jednak ze sobą przesycenie inwestycyjne i idące za tym problemy społeczne jak niedobory na rynku mieszkaniowym. Strategia dywersyfikacji funkcji metropolitarnych okazuje się interesującą metodą rozwiązującą problem ograniczonej ilości terenów inwestycyjnych kraju, szczególnie stolicy. Realizacja - często w ramach szerszej współpracy międzynarodowej wielkopowierzchniowych projektów urbanistycznych w partnerstwie publiczno-prywatnym pomaga utrzymać zrównoważony rozwój państwa. Ośrodki takie jak Kirchberg czy Nowe Belval niosą jednak groźbę powstawania struktur monokulturowych lub niezwiązanych kompozycyjnie i społecznie z istniejącą wokół strukturą miejską.

Rozwój miasta w oparciu o funkcjonalne monokultury prowadzi do polaryzacji tego organizmu i wzrostu ilości wykonywanych podróży. Mieszkańcy nie tylko spędzają większość czasu na podróżowaniu pomiędzy wyspecjalizowanymi dzielnicami, ale także władze miast muszą poświęcać więcej środków na obsługę infrastruktury transportowej. Obszary jednolite funkcjonalnie charakteryzują się również periodycznością swojej żywotności. Największe 
dzielnice biurowe po godzinach pracy pozostają opustoszałe, zaś mieszkańcy wracając tylko na noc do domów zlokalizowanych w dzielnicach zwanych miejskimi sypialniami tracą okazję na lepsze poznanie oraz utożsamienie się z okolicą swojego domu. Stan taki nie sprzyja również rozwojowi bliższych relacji społecznych, gdyż nawet funkcje rekreacyjne realizowane są w oddzielnych obszarach.

Inwestycje takie jak Nowe Belval, a szczególnie Clôche d’Or, ale także działania mające na celu urozmaicenie funkcjonalne Kirchbergu, pokazują pozytywny kierunek rozwoju wielkich założeń miejskich. Inwestycje te charakteryzują się właściwym wymieszaniem funkcji, chociaż dopiero Clôche d'Or prawidłowo integruje istniejącą tkankę miejską. Należy oczekiwać, że w kolejnych latach kierunek rozbudowy Esch-sur-Alzette przesunie środek ciężkości miasta bliżej huty Belval, pozwalając efektywniej wykorzystać potencjał nowej dzielnicy. 


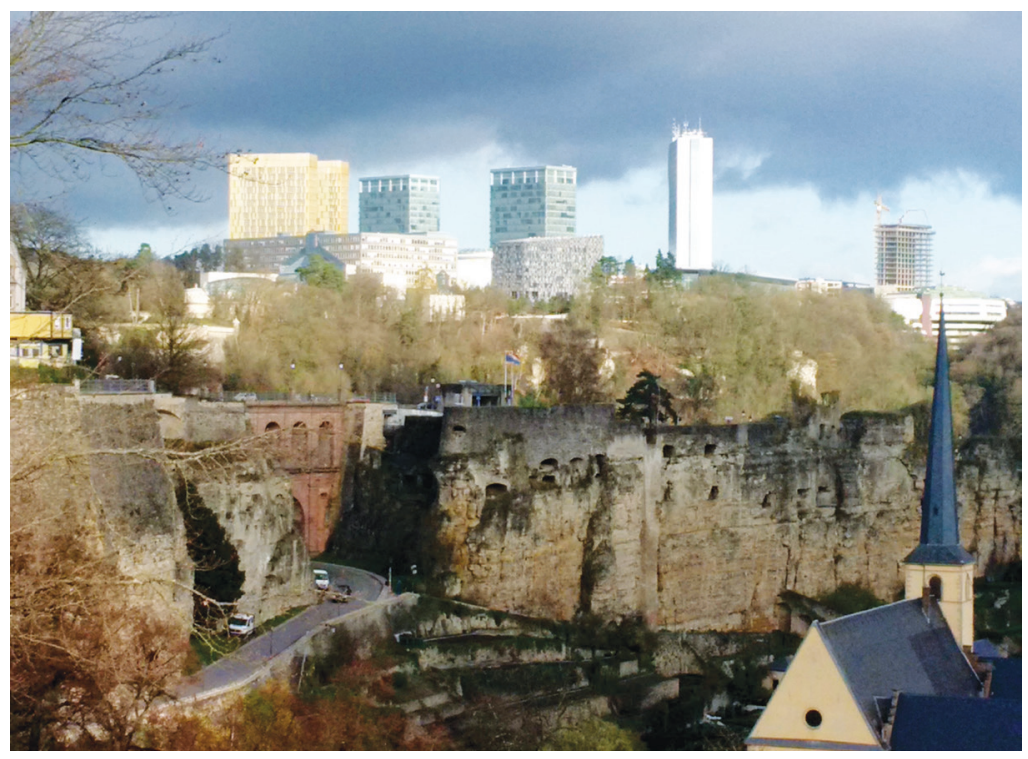

II. 1. Kichrberg widziany z centrum Luksemburga. Kirchberg seen from Luxembourg's centre. Autor: GilPe (źródło: https://commons.wikimedia.org/wiki/File:Luxembourg,_vue_Bock_-_Kirchberg_ (2).jpg; dostęp: 25.03.2018)

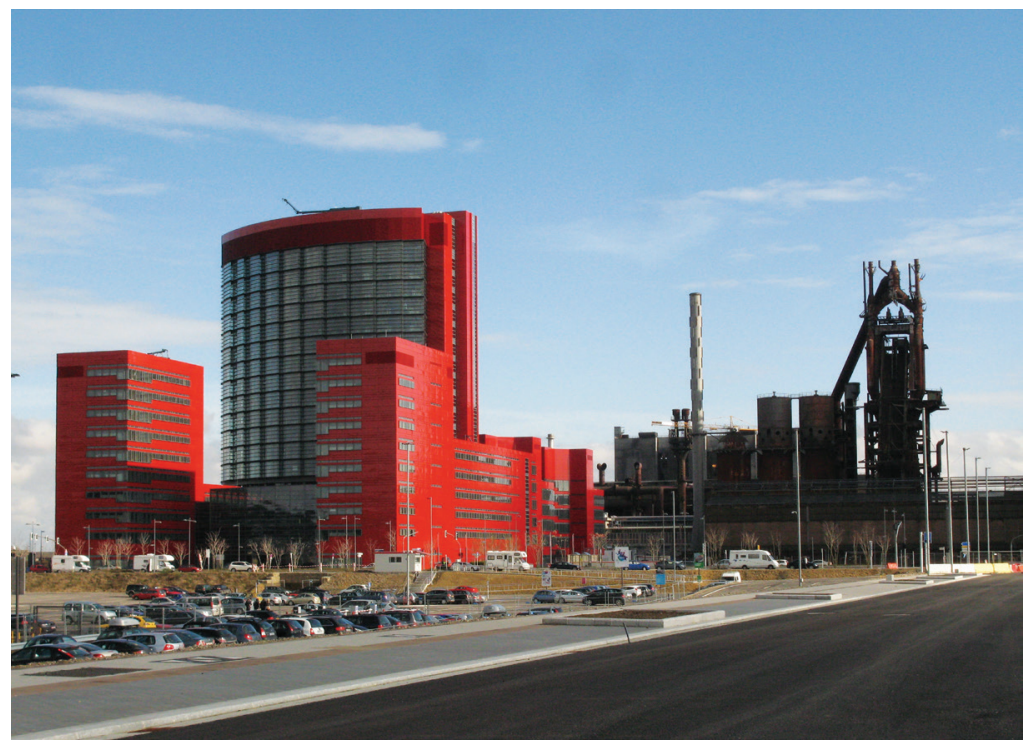

II. 2. Współczesny landmark dzielnicy Nowe Belval - biurowiec Dexia Belval. Present-day landmark of the new district New Belval - an office building Dexia Belval (źródło: https://commons.wikimedia.org/ wiki/File:Dexia_Belval.jpg autor Les Meloures; dostęp: 25.03.2018) 


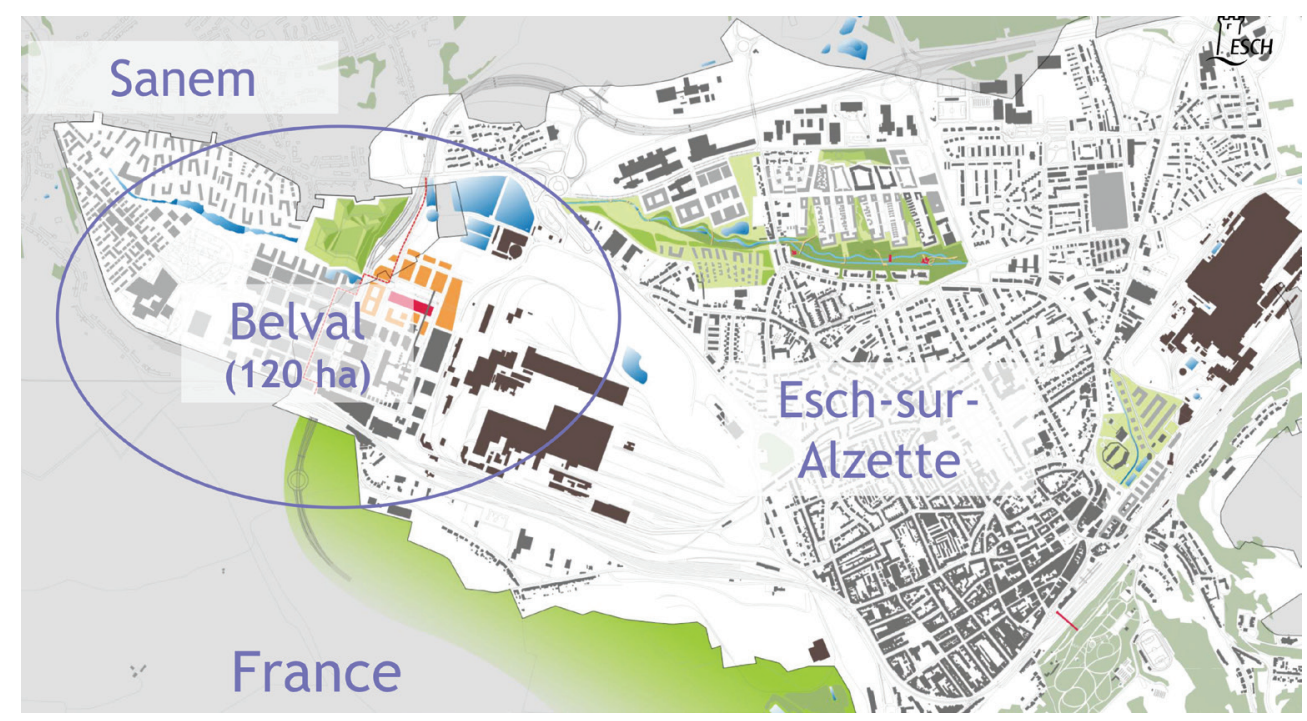

II. 3. Lokalizacja Nowego Belval w kontekście miejskim. Location of New Belval in the city context (źródło: ACodello, Esch-sur-Alzette, from the steel metropolis to the national hub of research and higher education, Esch-sur-Alzette 2015, www.esch.lu; dostęp: 25.03.2018)

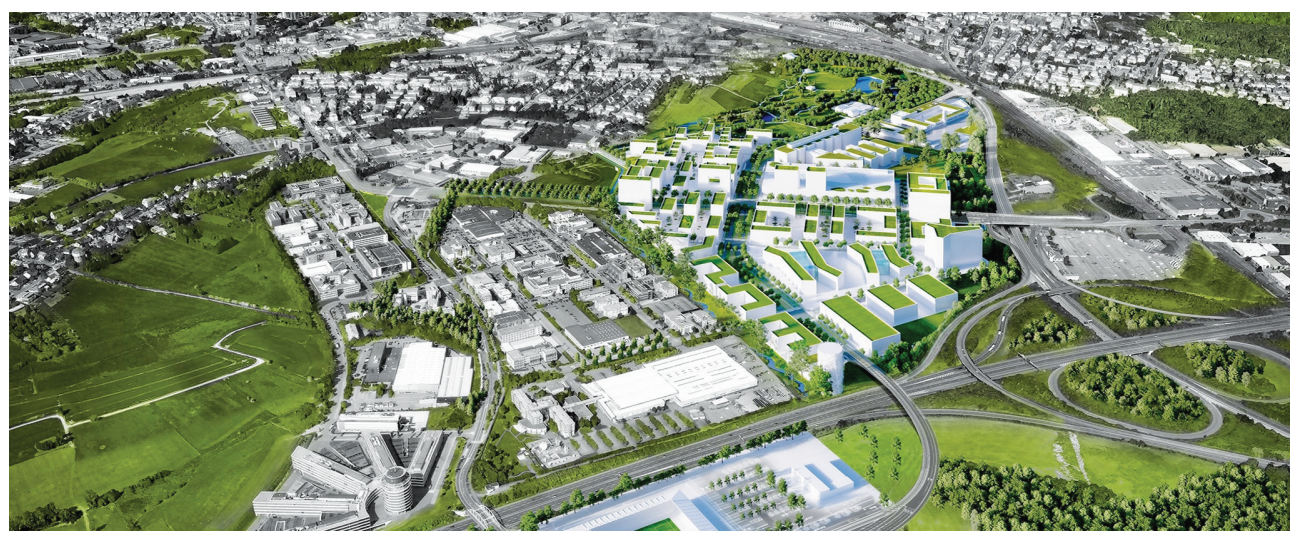

II. 4. Nowa dzielnica miasta Luksemburg - Clôche d'Or. New district of the city Luxembourg - Clôche d'Or (źródło: Luxembourg Times, https://luxtimes.lu/archives/164-allianz-buys-vertigo-office-complex-incloche-d-or; dostęp: 25.03.2018) 


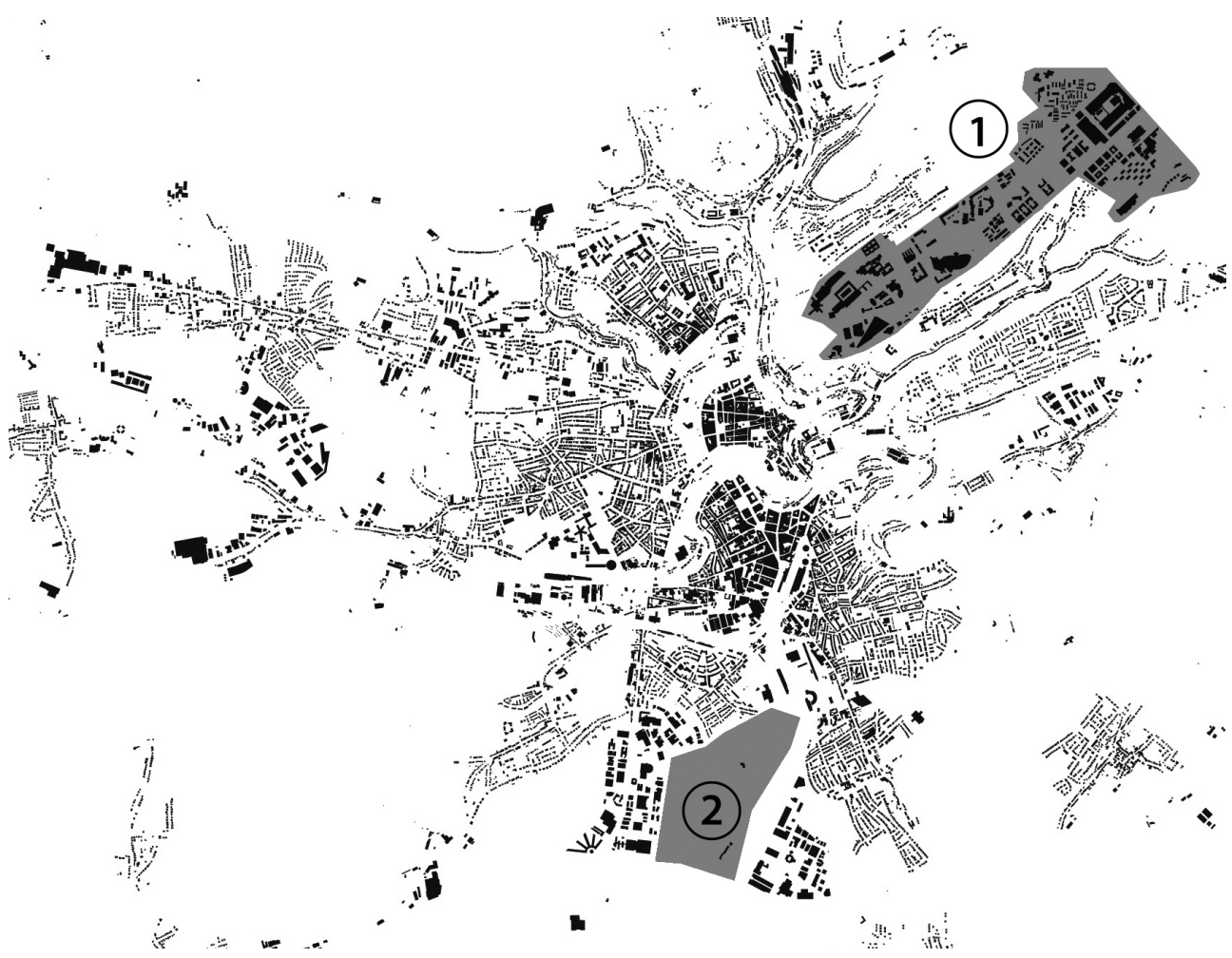

II. 5. Shwarzplan miasta Luksemburg: 1 - dzielnica Kirchberg, 2 - obszar realizacji dzielnicy Clôche d'Or. Shwarzplan of the city Luxembourg: 1 - Kirchberg district, 2 - an area of Clôche d'Or district (grafika: M. Dudek) 
PRZYPISY

1 M. Hesse, Das Kirchberg-Syndrom: grosse Projekte im kleinen Land: Bauen und Planen in Luxemburg, The Planning Review, 2013, 49:1, s. 14-28,

2 M. Hesse, On borrowed size, flawed urbanisation and emerging enclave spaces: The exceptional urbanism of Luxembourg, European Urban and Regional Studies, 2014, s. 1.

3 M. Hesse, op. cit., s. 14-28.

4 A. Leick, Large-Scale Urban Projects in Smaller Metro Areas: Towards a Broader Conceptual Perspective Planning, Practice \& Research, 2015, s. 54-68.

5 M. Hesse, op. cit., s. 5.

6 Ibidem, s. 14-28.

7 Ibidem, s. 2.

8 Trading Economics, https://pl.tradingeconomics.com/luxembourg/unemployment-rate (dostęp: 31.08.2017).

9 Ibidem.

10 M. Hesse, op. cit., s. 14-28.

11 Ibidem.

12 Strona Funduszu Kirchberg, http://www.fondskirchberg.lu/ (dostęp: 17.03.2018).

${ }^{13} \mathrm{D}$. Alderman, Esch-sur-Alzette, from the steel metropolis to the national hub of research and higher education, www.esch.lu (dostęp: 20.08.2017).

${ }^{14}$ Strona spółki Agora, http://www.agora.lu/en/ (dostęp: 20.08.2017).

15 Ibidem.

16 D. Nauroy, Projekt: Cloche d'Or: naissance d'un quartier, Luxemburger Wort, https://www. wort.lu/fr/luxembourg/projet-cloche-d-or-naissance-d-un-quartier (dostęp: 25.03.2018).

17 N. Schartz, Ban de Gasperich: Ein „Leuchtturm “ am Stadtrand, Luxemburger Wort, https://www. wort.lu/de/lokales/ban-de-gasperich-ein-leuchtturm-am-stadtrand (dostęp: 25.03.2018).

18 D. Codello, Esch-sur-Alzette, from the steel metropolis to the national hub of research and higher education www.esch.lu (dostęp: 20.08.2017).

${ }^{19}$ EcoCité, http://reseaux-chaleur.cerema.fr/projets-reseaux-de-chaleur-dans-le-cadre-des-ecocites (dostęp: 22.08.2017).

20 M. Hesse, op. cit., s. 2.

${ }^{21}$ Ibidem, s. 9. 


\section{BIBLIOGRAFIA}

Alderman D., Esch-sur-Alzette, from the steel metropolis to the national hub of research and higher education, www.esch.lu (dostęp: 20.08.2017).

Barrows L., Sustainability of Significant Urban Projects in Luxembourg, WorldWarch Institure Europe, http://www.worldwatch-europe.org/node/346 (dostęp: 18.08.2017).

Hesse M., On borrowed size, flawed urbanisation and emerging enclave spaces: The exceptional urbanism of Luxembourg, Luxembourg, European Urban and Regional Studies, 2014.

Hesse M., Das Kirchberg-Syndrom: grosse Projekte im kleinen Land: Bauen und Planen in Luxemburg, The Planning Review, 2013, 49:1.

Leick A., Large-Scale Urban Projects in Smaller Metro Areas: Towards a Broader Conceptual Perspective, Planning, Practice \& Research, 2015, Vol. 30, No. 1, 54-68.

Nauroy D., Projekt: Clôche d'Or: naissance d'un quartier" Luxemburger Wort, https://www. wort.lu/fr/luxembourg/projet-Clôche-d-or-naissance-d-un-quartier (dostęp: 25.03.2018).

Schartz N., Ban de Gasperich: Ein „Leuchtturm “ am Stadtrand” Luxemburger Wort, https://www. wort.lu/de/lokales/ban-de-gasperich-ein-leuchtturm-am-stadtrand (dostęp: 25.03.2018).

Strona projektu Nowe Belval - historia, http://www.belval.lu/fr/belval/histoire/ (dostęp: 20.08.2017).

Strona projektu Clôche d’Or, http://www.Clôchedor.lu/ (dostęp: 25.03.2018).

Strona Funduszu Le Fonds Belval, http://www.fonds-belval.lu/ (dostęp: 20.08.2017).

Strona Funduszu Kirchberg, http://www.fondskirchberg.lu/ (dostęp: 17.03.2018).

Strona spółki Agora, http://www.agora.lu/en/ (dostęp: 20.08.2017).

Strona Projektu EcoCité, http://reseaux-chaleur.cerema.fr/projets-reseaux-de-chaleur-dans-le-cadre-des-ecocites (dostęp: 22.08.2017).

Trading Economics, https://pl.tradingeconomics.com/luxembourg/unemployment-rate (dostęp: 31.08.2017).

ADRES BIBLIOGRAFICZNY ARTYKUŁU: Dudek M., Strategia dywersyfikacji w polityce przestrzennej Księstwa Luksemburga, Przestrzeń/Urbanistyka/Architektura, 1/2018, s. 7-20.

DATA AKCEPTACII OSTATECZNEJ WERSII DO OPUBLIKOWANIA: 20.06.2018. 